\title{
THE SYNTHESIS IMPACT ON DIELECTRIC PROPERTIES
}

\section{OF $\mathrm{La}_{0.5} \mathrm{Li}_{0.5-\mathrm{x}} \mathrm{Na}_{\mathrm{x}} \mathrm{TiO}_{3}$}

\section{T.O. Plutenko, O.I. V'yunov *, O.P. Fedorchuk, O.Z. Yanchevskii, A.G. Belous}

V.I. Vernadsky Institute of General and Inorganic Chemistry of National Academy of Sciences of Ukraine, Akad. Palladin ave, 32/34, Kyiv, 03142, Ukraine

e-mail:vyunov@ionc.kiev.ua

Using X-ray powder, diffraction the sequence of reactions occurring during the synthesis $\mathrm{La}_{0.5} \mathrm{Li}_{0.5-\mathrm{x}} \mathrm{Na}_{\mathrm{x}} \mathrm{TiO}_{3}$ by solid-state reaction technique has been determined. Using electron microscopy it has been shown that the grain size decreases with increasing $x$ in $\mathrm{La}_{0.5} \mathrm{Li}_{0.5-\mathrm{x}} \mathrm{Na}_{\mathrm{x}}$ $\mathrm{TiO}_{3}$ system. The influence of the grain size of ceramics on the dielectric characteristics has been indicated. The frequency dependences of permittivity and dielectric loss tangent have been investigated by ac impedance spectroscopy. It has been established that ceramic sample of $\mathrm{La}_{0.5} \mathrm{Li}_{0.4} \mathrm{Na}_{0.1} \mathrm{TiO}_{3}$ solid solution has the largest value of permittivity $\varepsilon>10^{4}$ at wide frequency range $\left(1-10^{4} \mathrm{~Hz}\right)$ in $\mathrm{La}_{0.5} \mathrm{Li}_{0.5-\mathrm{x}} \mathrm{Na}_{\mathrm{x}} \mathrm{TiO}_{3}$ system.

Keywords: solid solution, lithium-sodium-lanthanum titanate, perovskite, complex impedance, colossal permittivity.

INTRODUCTION. LLTO and other $\mathrm{ABO}_{3}$ perovskites attract great attention for the last years and are investigated intensively. These materials can be used in microelectronics and electrochemical devices. One of the conductive perovskites applications is the development of electrolytes for lithium-ion batteries, which are for now the criticaltechnologyin energystorage. Such solid electrolytes have crucial advantages over liquid analogs: nonflammability and generally improved safety (critical for power supplies of vehicles), low-temperature stability, higher power, and energy densities $[1,2]$. There are other different classes of materials for solid electrolytes: phosphates on the base of NASICON, LISICON, garnets [3- 5].
But LLTO stands out due to relatively high conductivity $\sigma=10^{-3} \mathrm{~S} / \mathrm{cm}$ for bulk samples [6]. It is the ion-conducting material, in which the high ionic conductivity provided by lithium transport through vacancies in A-sublattice, formed by lanthanum and substituting ions and surrounded by oxygen ions, in the perovskite structure.

Perovskite-based materials also demonstrate the giant dielectric constant [7]. High dielectric constant $\left(\varepsilon^{\prime}=10^{3}-10^{6}\right)$ is the key feature for further miniaturization of microelectronics components, development of capacitors for high-energy storage (Multi-Layer Ceramic Capacitors [8]). LLTO-based materials are also remarkable among other perovskites 
due to the stability of properties in a wide temperature range [7]. One of such materials is, for example, $\mathrm{La}_{0.67} \mathrm{Li}_{0.25} \mathrm{Ti}_{0.75} \mathrm{Al}_{0.25} \mathrm{O}_{3}$ ceramics. It was revealed, that high dielectric permittivity in the case of $\mathrm{La}_{0.67} \mathrm{Li}_{0.25} \mathrm{Ti}_{0.75} \mathrm{Al}_{0.25} \mathrm{O}_{3}$ is associated with the barrier layer capacitor effect, caused by the depletion of $\mathrm{Li}$ ions at the grain boundaries. Therefore, conductivity, structural and morphological features of LLTO have a considerable impact on the giant dielectric constant in it.

It was found that in the $\mathrm{La}_{0.5} \mathrm{Na}_{0.5} \mathrm{TiO}_{3}$ (LNTO) material high dielectric constant is due to the heterogeneous distribution of cations, which leads to a strong local field fraction [9]. It was also shown that solid solutions are formed in the system $\mathrm{La}_{0.5} \mathrm{Li}_{0.5-\mathrm{x}} \mathrm{Na}_{\mathrm{x}} \mathrm{TiO}_{3}$ (LLNTO) [10]. The dielectric properties of LLNTO have been studied in the microwave region. It can be assumed that in the frequency range of $10^{0}-10^{6} \mathrm{~Hz}$ the presence of sodium will lead to a strong change in the dielectric properties. At first sight, sodium has a big ionic radius and causes many effects, leading to reduction in both conductivity and dielectric constant [10]. It decreases the concentration of mobile charge carriers; reduces the number of vacancies in A site. But also sodium provokes shifts in the crystal structure of perovskite and has an ambiguous impact on resulting properties [11-13].

Despite the long-lasting studies, there are many open challenges regarding lithium conductive perovskites. It is known, for example, that synthesis of these ones is a complex and hard task. Almost all of the existing works concentrated on the final properties of obtained materials without the understanding of intermediate processes during the synthesis. In this paper, we studied the formation and changes of transitional phases during the $\mathrm{La}_{0}$.
${ }_{5} \mathrm{Li}_{0.5-\mathrm{x}} \mathrm{Na}_{\mathrm{x}} \mathrm{TiO}_{3}$ ceramics synthesis by solid-state reactions technique in a temperature range $20-1300{ }^{\circ} \mathrm{C}$ as an attempt to clarify the nature of these processes. In addition, we studied the effect of increasing sodium concentration on dielectric properties of $\mathrm{La}_{0.5} \mathrm{Li}_{0.5-\mathrm{x}} \mathrm{Na}_{\mathrm{x}} \mathrm{TiO}_{3}$.

EXPERIMENT AND DISCUSSION OF THE RESULTS. Samples were obtained from stoichiometric amounts of dried $\mathrm{Li}_{2} \mathrm{CO}_{3}$ (Merck), $\mathrm{Na}_{2} \mathrm{CO}_{3}$ (Merck), $\mathrm{La}_{2} \mathrm{O}_{3}$ (Aldrich 99.99\%), and $\mathrm{TiO}_{2}$ (Aldrich $99 \%$ ) by solid-state reaction technique. $\mathrm{Li}_{2} \mathrm{CO}_{3}$ and $\mathrm{Na}_{2} \mathrm{CO}_{3}$ compounds were dried at $300{ }^{\circ} \mathrm{C}, \mathrm{La}_{2} \mathrm{O}_{3}$ at $800{ }^{\circ} \mathrm{C}$, and $\mathrm{TiO}_{2}$ at $600{ }^{\circ} \mathrm{C}$. The mixtures of $\mathrm{Li}_{2} \mathrm{CO}_{3}, \mathrm{Na}_{2} \mathrm{CO}_{3}$, $\mathrm{La}_{2} \mathrm{O}_{3}$, and $\mathrm{TiO}_{2}$ were ground in an agate mortar with acetone, and calcined in air for $4 \mathrm{~h}$ at $1250^{\circ} \mathrm{C}$. The rate of temperature increase was $200^{\circ} \mathrm{C} /$ hour. The phases were characterized by X-ray powder diffractometry (XRPD) using DRON-4-07 diffractometer $(\mathrm{Cu}$ Ka radiation; $40 \mathrm{kV}, 20 \mathrm{~mA}$ ). The calcined powders were ground and pressed into pellets with a diameter of $10 \mathrm{~mm}$ and a thickness of $6 \mathrm{~mm}$ under a pressure of $500 \mathrm{~kg} / \mathrm{cm}^{2}(50 \mathrm{MPa})$. The pellets were sintered at $1300-1330{ }^{\circ} \mathrm{C}$ depending on $\mathrm{Na}$ content $(6 \mathrm{~h})$. Finally, samples with $1 \mathrm{~mm}$ thickness were cut out from prepared raw ceramic.

In order to determine intermediate phases during synthesis, isothermal heat treatment was carried out in the temperature range from room temperature (RT) to $1300{ }^{\circ} \mathrm{C}$ during $2 \mathrm{~h}$. The change in the phase composition was studied in the temperature range $20-1100{ }^{\circ} \mathrm{C}$ by method $\mathrm{X}$-ray phase diffraction (XRD) analysis using DRON-4-07 CuKa-radiation; $40 \mathrm{kV}, 20 \mathrm{~mA}$ ). $\mathrm{SiO}_{2}$ and $\mathrm{Al}_{2} \mathrm{O}_{3}$ were used as external standards (for $2 \Theta$ and intensity).

Grain sizes of ceramic samples of $\mathrm{La}_{0.5} \mathrm{Li}_{0.5-\mathrm{x}} \mathrm{Na}_{\mathrm{x}} \mathrm{TiO}_{3}$ system (where $0 \leq \mathrm{x} \leq 0.5$ ) 
were determined using a scanning electron microscope JEM 10CX II (JEOL) and scanning electron microscope SEC miniSEM SNE 4500MB equipped with EDAX Element PV6500/00 F spectrometer. Sintered cylindrical pellets $10 \mathrm{~mm}$ in diameter and $2 \mathrm{~mm}$ thick, with evaporated electrodes, were used for electrical measurements.

Impedance spectroscopy measurements were performed using a 1260 Impedance / Gain phase Analyzer (Solartron Analytical).

Using X-ray powder diffraction analysis it has been shown that single-phase solid solutions in $\mathrm{La}_{0.5} \mathrm{Li}_{0.5-\mathrm{x}} \mathrm{Na}_{\mathrm{x}} \mathrm{TiO}_{3}$ system are formed at temperatures above $1200^{\circ} \mathrm{C}$ (Fig. 1). All samples of $\mathrm{La}_{0.5} \mathrm{Li}_{0.5-\mathrm{x}} \mathrm{Na}_{\mathrm{x}} \mathrm{TiO}_{3}$ system have rhombohedral (trigonal) symmetry with space group R-3c. The parameters of the unit cell were calculated by the full-profile Rietveld analysis. As can be seen from Fig. 2, the parameters of the unit cell in the $\mathrm{La}_{0.5} \mathrm{Li}_{0.5-\mathrm{x}} \mathrm{Na}_{\mathrm{x}} \mathrm{TiO}_{3}$ system change by Vegard's law, which indicates the formation of solid solutions. The increase in the volume of the unit cell with increasing $\mathrm{x}$ is explained by the rise in the average ionic radius in the lithium-sodium sublattice.

Intermediate phases of synthesis depending on the temperature of calcination are presented in Table 1.

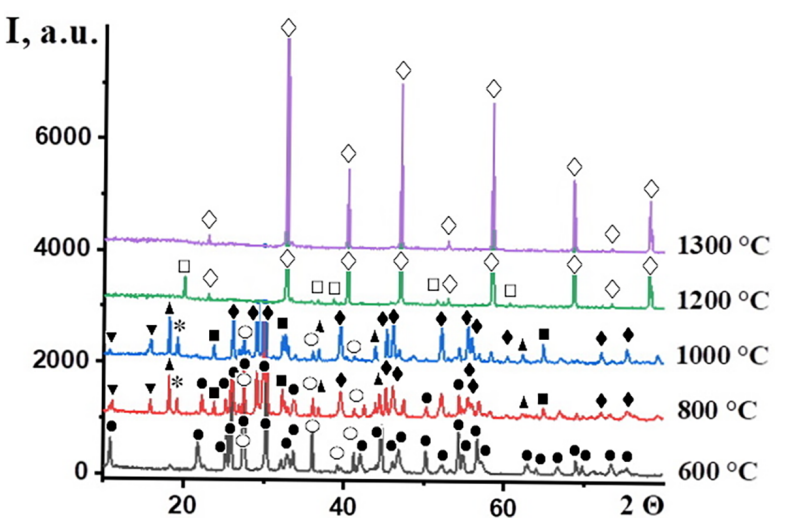

Fig. 1. X-ray powder diffraction analysis of $\mathrm{La}_{0.5} \mathrm{Li}_{0.5-\mathrm{x}} \mathrm{Na}_{\mathrm{x}} \mathrm{TiO}_{3}$ at $x=0.2$, calcined at different temperatures. Marked phases $\mathrm{La}_{0,5} \mathrm{Li}_{0,3} \mathrm{Na}_{0,2} \mathrm{TiO}_{3}(\theta)$, $\mathrm{La}_{05} \mathrm{Na}_{05} \mathrm{TiO}_{3}(\square), \mathrm{La}_{2} \mathrm{O}_{2} \mathrm{CO}_{3}(\bullet), \mathrm{TiO}_{2}(0), \mathrm{Na}_{2} \mathrm{Ti}_{3} \mathrm{O}_{7}$ $(\boldsymbol{\nabla}), \mathrm{Li}_{2} \mathrm{Ti}_{2} \mathrm{O}_{5}(\boldsymbol{\Delta}), \mathrm{Na}_{2} \mathrm{Ti}_{2} \mathrm{O}_{5}(*), \mathrm{La}_{2} \mathrm{O}_{3}(\bullet), \mathrm{La}_{2} \mathrm{Ti}_{2} \mathrm{O}_{7}$ (घ).

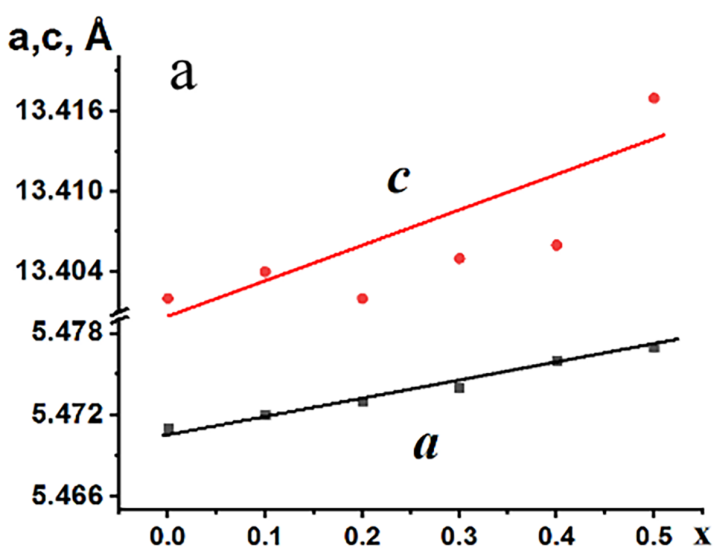

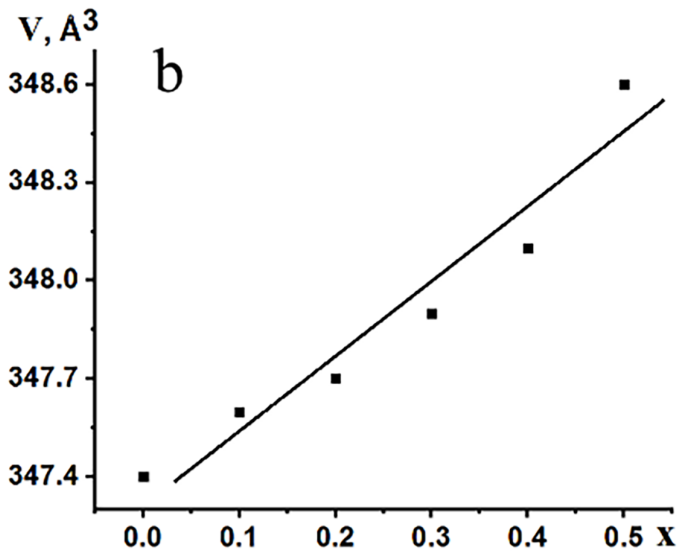

Fig. 2. Dependence of the unit cell parameters a, $c$ (a) and unit cell volume $V\left(\right.$ b) of $\mathrm{La}_{0.5} \mathrm{Li}_{0.5-\mathrm{x}} \mathrm{Na}_{\mathrm{x}} \mathrm{TiO}_{3}$ on $\mathrm{x}$. 
Phase composition of powders in the $\mathrm{La}_{0.5} \mathrm{Li}_{0.5-\mathrm{x}} \mathrm{Na}_{\mathrm{x}} \mathrm{TiO}_{3}$ system

Table 1

\begin{tabular}{|c|c|c|c|}
\hline $\mathrm{T},{ }^{\circ} \mathrm{C}$ & $\mathbf{x}=0$ & $\mathbf{x}=0.2$ & $\mathbf{x}=0.5$ \\
\hline $20-400$ & $\mathrm{Li}_{2} \mathrm{CO}_{3}, \mathrm{TiO}_{2}, \mathrm{La}(\mathrm{OH})_{3}$ & $\mathrm{Na}_{2} \mathrm{CO}_{3}, \mathrm{Li}_{2} \mathrm{CO}_{3}, \mathrm{TiO}_{2}, \mathrm{La}(\mathrm{OH})_{3}$ & $\mathrm{TiO}_{2}, \mathrm{Na}_{2} \mathrm{CO}_{3}, \mathrm{La}(\mathrm{OH})_{3}$ \\
\hline 500 & $\mathrm{TiO}_{2}, \mathrm{Li}_{2} \mathrm{TiO}_{3}, \mathrm{La}_{2} \mathrm{O}_{2} \mathrm{CO}_{3}$ & $\mathrm{TiO}_{2}, \mathrm{Li}_{2} \mathrm{TiO}_{3}, \mathrm{Na}_{2} \mathrm{CO}_{3}, \mathrm{La}_{2} \mathrm{O}_{2} \mathrm{CO}_{3}$ & $\mathrm{TiO}_{2}, \mathrm{Na}_{2} \mathrm{CO}_{3}, \mathrm{La}_{2} \mathrm{O}_{2} \mathrm{CO}_{3}$ \\
\hline 600 & $\mathrm{TiO}_{2}, \mathrm{Li}_{2} \mathrm{TiO}_{3}, \mathrm{La}_{2} \mathrm{O}_{3}$ & $\mathrm{TiO}_{2}, \mathrm{Li}_{2} \mathrm{TiO}_{3}, \mathrm{Na}_{2} \mathrm{CO}_{3}, \mathrm{La}_{2} \mathrm{O}_{2} \mathrm{CO}_{3}$ & $\mathrm{TiO}_{2}, \mathrm{Na}_{2} \mathrm{CO}_{3}, \mathrm{La}_{2} \mathrm{O}_{2} \mathrm{CO}_{3}$ \\
\hline 800 & $\mathrm{TiO}_{2}, \mathrm{Li}_{2} \mathrm{Ti}_{2} \mathrm{O}_{5}, \mathrm{La}_{2} \mathrm{Ti}_{2} \mathrm{O}_{7}$ & $\begin{array}{l}\mathrm{TiO}_{2}, \mathrm{La}_{2} \mathrm{O}_{2} \mathrm{CO}_{3}, \mathrm{La}_{2} \mathrm{O}_{3}, \mathrm{Li}_{2} \mathrm{Ti}_{2} \mathrm{O}_{5}, \\
\mathrm{Na}_{2} \mathrm{Ti}_{2} \mathrm{O}_{5}, \mathrm{Na}_{2} \mathrm{Ti}_{3} \mathrm{O}_{7}\end{array}$ & $\begin{array}{l}\mathrm{TiO}_{2}, \mathrm{La}_{2} \mathrm{O}_{2} \mathrm{CO}_{3}, \mathrm{La}_{2} \mathrm{O}_{3}, \\
\mathrm{Na}_{2} \mathrm{Ti}_{2} \mathrm{O}_{5}, \mathrm{Na}_{2} \mathrm{Ti}_{3} \mathrm{O}_{7}, \mathrm{Na}_{2} \mathrm{TiO}_{3}\end{array}$ \\
\hline 900 & $\begin{array}{l}\mathrm{TiO}_{2}, \mathrm{La}_{2} \mathrm{O}_{3}, \\
\mathrm{La}_{0.5} \mathrm{Li}_{0.5} \mathrm{TiO}_{3}, \mathrm{Li}_{2} \mathrm{Ti}_{2} \mathrm{O}_{5}, \\
\mathrm{Li}_{2} \mathrm{Ti}_{3} \mathrm{O}_{7}, \mathrm{La}_{2} \mathrm{Ti}_{2} \mathrm{O}_{7}\end{array}$ & $\begin{array}{l}\mathrm{TiO}_{2}, \mathrm{La}_{2} \mathrm{O}_{3}, \mathrm{La}_{2} \mathrm{Ti}_{2} \mathrm{O}_{7}, \\
\mathrm{La}_{0.5} \mathrm{Li}_{0.5} \mathrm{TiO}_{3}, \mathrm{Li}_{2} \mathrm{Ti}_{2} \mathrm{O}_{5}, \mathrm{Li}_{2} \mathrm{Ti}_{3} \mathrm{O}_{7}, \\
\mathrm{Na}_{2} \mathrm{Ti}_{2} \mathrm{O}_{5}, \mathrm{Li}_{4} \mathrm{Ti}_{5} \mathrm{O}_{12}\end{array}$ & $\begin{array}{l}\mathrm{TiO}_{2}, \mathrm{La}_{2} \mathrm{O}_{3}, \mathrm{Na}_{2} \mathrm{Ti}_{2} \mathrm{O}_{5} \\
\mathrm{Na}_{2} \mathrm{Ti}_{3} \mathrm{O}_{7}, \mathrm{Na}_{2} \mathrm{TiO}_{3}\end{array}$ \\
\hline 1000 & $\begin{array}{l}\mathrm{TiO}_{2}, \mathrm{La}_{2} \mathrm{O}_{3}, \\
\mathrm{La}_{0.5} \mathrm{Li}_{0.5} \mathrm{TiO}_{3}, \mathrm{Li}_{2} \mathrm{Ti}_{2} \mathrm{O}_{5}, \\
\mathrm{Li}_{2} \mathrm{Ti}_{3} \mathrm{O}_{7}, \mathrm{La}_{2} \mathrm{Ti}_{2} \mathrm{O}_{7}\end{array}$ & $\begin{array}{l}\mathrm{TiO}_{2}, \mathrm{La}_{2} \mathrm{O}_{3}, \mathrm{La}_{2} \mathrm{Ti}_{2} \mathrm{O}_{7}, \\
\mathrm{La}_{2.5} \mathrm{Li}_{0.5} \mathrm{TiO}_{3}, \mathrm{Li}_{2} \mathrm{Ti}_{2} \mathrm{O}_{5}, \mathrm{Li}_{2} \mathrm{Ti}_{3} \mathrm{O}_{7}, \\
\mathrm{Na}_{2} \mathrm{Ti}_{2} \mathrm{O}_{5}, \mathrm{Na}_{2} \mathrm{TiO}_{3}, \mathrm{NaLiTi}_{3} \mathrm{O}_{7}, \\
\mathrm{Li}_{4} \mathrm{Ti}_{5} \mathrm{O}_{12}\end{array}$ & $\begin{array}{l}\mathrm{TiO}_{2}, \mathrm{La}_{2} \mathrm{O}_{3}, \mathrm{La}_{2} \mathrm{Ti}_{2} \mathrm{O}_{7}, \\
\mathrm{Na}_{2} \mathrm{Ti}_{2} \mathrm{O}_{5}, \mathrm{Na}_{2} \mathrm{Ti}_{3} \mathrm{O}_{7}, \mathrm{Na}_{2} \mathrm{TiO}_{3}, \\
\mathrm{Na}_{4} \mathrm{Ti}_{5} \mathrm{O}_{12}\end{array}$ \\
\hline 1100 & $\begin{array}{l}\mathrm{Li}_{2} \mathrm{Ti}_{2} \mathrm{O}_{5}, \mathrm{La}_{0.5} \mathrm{Li}_{0.5} \mathrm{TiO}_{3}, \\
\mathrm{La}_{2} \mathrm{Ti}_{2} \mathrm{O}_{7}\end{array}$ & $\begin{array}{l}\mathrm{Li}_{2} \mathrm{Ti}_{2} \mathrm{O}_{5}, \mathrm{Na}_{2} \mathrm{Ti}_{2} \mathrm{O}_{5}, \mathrm{La}_{0.5} \mathrm{Li}_{0.5} \mathrm{TiO}_{3}, \\
\mathrm{La}_{0.5} \mathrm{Na}_{0.5} \mathrm{TiO}_{3}, \mathrm{La}_{2} \mathrm{Ti}_{2} \mathrm{O}_{7}\end{array}$ & $\begin{array}{l}\mathrm{Na}_{2} \mathrm{Ti}_{2} \mathrm{O}_{5}, \mathrm{La}_{2} \mathrm{Ti}_{2} \mathrm{O}_{7}, \\
\mathrm{La}_{0.5} \mathrm{Na}_{0.5} \mathrm{TiO}_{3}\end{array}$ \\
\hline 1200 & $\mathrm{La}_{0.5} \mathrm{Li}_{0.5} \mathrm{TiO}_{3}$ & $\begin{array}{l}\mathrm{La}_{0.5} \mathrm{Li}_{0.3} \mathrm{Na}_{0.2} \mathrm{TiO}_{3}, \mathrm{La}_{0.5} \mathrm{Li}_{0.5} \mathrm{TiO}_{3}, \\
\mathrm{La}_{0.5} \mathrm{Na}_{0.5} \mathrm{TiO}_{3}\end{array}$ & $\mathrm{La}_{0.5} \mathrm{Na}_{0.5} \mathrm{TiO}_{3}$ \\
\hline 1300 & $\mathrm{La}_{0.5} \mathrm{Li}_{0.5} \mathrm{TiO}_{3}$ & $\mathrm{La}_{0.5} \mathrm{Li}_{0.3} \mathrm{Na}_{0.2} \mathrm{TiO}_{3}$ & $\mathrm{La}_{0.5} \mathrm{Na}_{0.5} \mathrm{TiO}_{3}$ \\
\hline
\end{tabular}

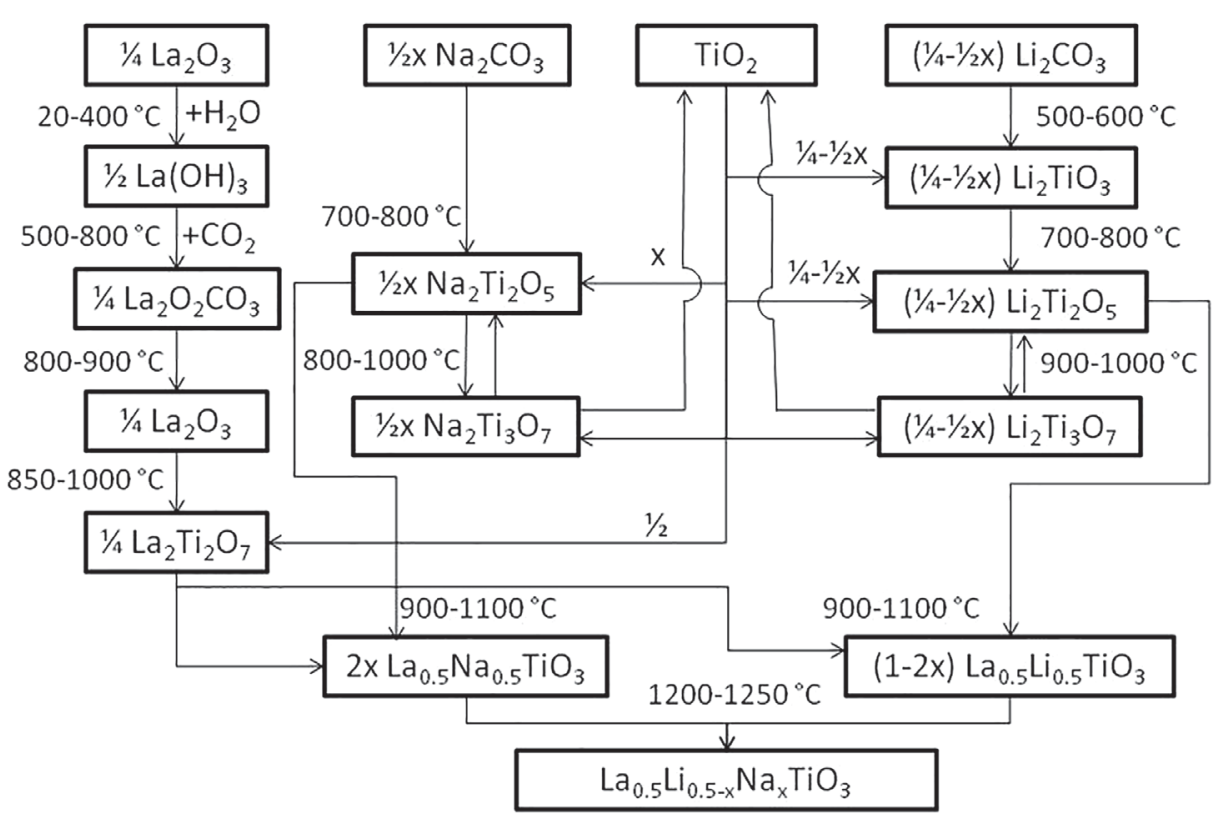

Fig. 3. Scheme of the $\mathrm{La}_{0.5} \mathrm{Li}_{0.5-\mathrm{x}} \mathrm{Na}_{\mathrm{x}} \mathrm{TiO}_{3}$ solid solutions synthesis by the solid-state reaction technique. 
The scheme of phase transformation occurring during $\mathrm{La}_{0.5} \mathrm{Li}_{0,5-\mathrm{x}} \mathrm{Na}_{\mathrm{x}} \mathrm{TiO}_{3}$ synthesis by the solid-state reaction technique is presented in Fig. 3.

Synthesis by the solid-state reaction technique is a complex and multi-stage process. At room temperature in contact with air $\mathrm{La}_{2} \mathrm{O}_{3}$ absorbs water and forms lanthanum hydroxide $\mathrm{La}(\mathrm{OH})_{3}$ :

$$
\mathrm{La}_{2} \mathrm{O}_{3}+3 \mathrm{H}_{2} \mathrm{O} \stackrel{20-400{ }^{\circ} \mathrm{C}}{\longrightarrow} 2 \mathrm{La}(\mathrm{OH})_{3}
$$

At higher temperatures, lanthanum hydroxide intensively adsorbs carbon dioxide producing lanthanum dioxycarbonate.

$$
2 \mathrm{La}(\mathrm{OH})_{3}+\mathrm{CO}_{2} \underset{500-800{ }^{\circ} \mathrm{C}}{\longrightarrow} \mathrm{La}_{2} \mathrm{O}_{2} \mathrm{CO}_{3}+3 \mathrm{H}_{2} \mathrm{O}
$$

Titanium (IV) oxide react with lithium carbonate to produce lithium metatitanate and carbon dioxide:

$$
\mathrm{Li}_{2} \mathrm{CO}_{3}+\mathrm{TiO}_{2} \underset{500-600{ }^{\circ} \mathrm{C}}{\longrightarrow} \mathrm{Li}_{2} \mathrm{TiO}_{3}+\mathrm{CO}_{2} \uparrow
$$

In the temperature range from 700 to $800{ }^{\circ} \mathrm{C}$ a reaction between lithium metatitanate and titanium (IV) oxide and the formation of $\mathrm{Li}_{2} \mathrm{Ti}_{2} \mathrm{O}_{5}$ takes place.

$$
\begin{gathered}
\mathrm{Li}_{2} \mathrm{TiO}_{3}+\mathrm{TiO}_{2} \stackrel{700-800^{\circ} \mathrm{C}}{\longrightarrow} \mathrm{Li}_{2} \mathrm{Ti}_{2} \mathrm{O}_{5} \\
\mathrm{Na}_{2} \mathrm{CO}_{3}+2 \mathrm{TiO}_{2} \stackrel{700-800^{\circ} \mathrm{C}}{\longrightarrow} \mathrm{Na}_{2} \mathrm{Ti}_{2} \mathrm{O}_{5}+\mathrm{CO}_{2} \uparrow
\end{gathered}
$$

Decomposition of lanthanum dioxycarbonate leads to $\mathrm{La}_{2} \mathrm{O}_{3}$ formation:

$$
\mathrm{La}_{2} \mathrm{O}_{2} \mathrm{CO}_{3} \stackrel{800-900{ }^{\circ} \mathrm{C}}{\longrightarrow} \mathrm{La}_{2} \mathrm{O}_{3}+\mathrm{CO}_{2} \uparrow
$$

Complicated parallel processes of $\mathrm{Na}_{2} \mathrm{Ti}_{3} \mathrm{O}_{7}$ formation can be presented by:

$$
\mathrm{Na}_{2} \mathrm{Ti}_{2} \mathrm{O}_{5}+\mathrm{TiO}_{2} \stackrel{800-1000^{\circ} \mathrm{C}}{\longrightarrow} \mathrm{Na}_{2} \mathrm{Ti}_{3} \mathrm{O}_{7}
$$

Formation of $\mathrm{La}_{2} \mathrm{Ti}_{2} \mathrm{O}_{7}$ occurs during the reaction between lanthanum hydroxide and titanium (IV) oxide:

$$
\mathrm{La}_{2} \mathrm{O}_{3}+2 \mathrm{TiO}_{2} \stackrel{850-1000^{\circ} \mathrm{C}}{\longrightarrow} \mathrm{La}_{2} \mathrm{Ti}_{2} \mathrm{O}_{7}
$$

$\mathrm{Li}_{2} \mathrm{Ti}_{2} \mathrm{O}_{5}$ phase reacts with $\mathrm{La}_{2} \mathrm{Ti}_{2} \mathrm{O}_{7}$ to form $\mathrm{La}_{0.5} \mathrm{Li}_{0.5} \mathrm{TiO}_{3}$

$$
\mathrm{Li}_{2} \mathrm{Ti}_{2} \mathrm{O}_{5}+\mathrm{La}_{2} \mathrm{Ti}_{2} \mathrm{O}_{7} \stackrel{900-1100^{\circ} \mathrm{C}}{\longrightarrow} 4 \mathrm{La}_{0.5} \mathrm{Li}_{0.5} \mathrm{TiO}_{3}
$$

At the same time parallel processes of $\mathrm{Li}_{2} \mathrm{Ti}_{3} \mathrm{O}_{7}$ formation/decomposition occur:

$$
\mathrm{Li}_{2} \mathrm{Ti}_{2} \mathrm{O}_{5}+\mathrm{TiO}_{2} \stackrel{900-1000^{\circ} \mathrm{C}}{\longrightarrow} \mathrm{Li}_{2} \mathrm{Ti}_{3} \mathrm{O}_{7}
$$

$\mathrm{Na}_{2} \mathrm{Ti}_{2} \mathrm{O}_{5}+\mathrm{La}_{2} \mathrm{Ti}_{2} \mathrm{O}_{7} \stackrel{800-1100{ }^{\circ} \mathrm{C}}{\longrightarrow} 4 \mathrm{La}_{0.5} \mathrm{Na}_{0.5} \mathrm{TiO}_{3}$

After all, solid solution $\mathrm{La}_{0.5} \mathrm{Li}_{0.5-\mathrm{x}} \mathrm{Na}_{\mathrm{x}} \mathrm{TiO}_{3}$ is formed by the interaction of two perovskite phases of $\mathrm{La}_{0.5} \mathrm{Na}_{0.5} \mathrm{TiO}_{3}$ and $\mathrm{La}_{0.5} \mathrm{Li}_{0.5} \mathrm{TiO}_{3}$ :

$$
\begin{gathered}
x \mathrm{La}_{0.5} \mathrm{Na}_{0.5} \mathrm{TiO}_{3}+(1-x) \mathrm{La}_{0.5} \mathrm{Li}_{0.5} \mathrm{TiO}_{3} \stackrel{1200-1250^{\circ} \mathrm{C}}{\longrightarrow} \\
\stackrel{1200-1250^{\circ} \mathrm{C}}{\longrightarrow} \mathrm{La}_{0.5} \mathrm{Li}_{0.5-\mathrm{x}} \mathrm{Na}_{\mathrm{x}} \mathrm{TiO}_{3}
\end{gathered}
$$

Fig. 4 shows SEM photographs of $\mathrm{La}_{0.5} \mathrm{Li}_{0.5-\mathrm{x}} \mathrm{Na}_{\mathrm{x}} \mathrm{TiO}_{3}$ samples. The grain size of ceramics in $\mathrm{La}_{0.5} \mathrm{Li}_{0.5-\mathrm{x}} \mathrm{Na}_{\mathrm{x}} \mathrm{TiO}_{3}$ solid solutions decreases from 4.5 to $3.5 \mu \mathrm{m}$ for $\mathrm{x}=0.15$ and 0.35 , respectively. Sintering reduces surface area by growing bonds between contacting particles during heating. Due to random orientations of the particles, the bond forms with an embedded grain boundary accommodating the crystal disorientation between particles. Effectively, early sinter bonding replaces surface area with a lower energy of grain boundary area. As surface area is annihilated, the driving force of the process declines, resulting in slower sintering rates. Mass transport mechanisms act a great role during sintering. From one point of view, the sintering temperature of $\mathrm{La}_{0.5} \mathrm{Li}_{0.5-\mathrm{x}} \mathrm{Na}_{\mathrm{x}} \mathrm{TiO}_{3}$ rises with $\mathrm{x}$ and this must lead to an increase in grain size of ceramics. On the other hand, the solid solution contains elements $\mathrm{Li}$ and $\mathrm{Na}$ that tend to evaporate at high temperatures, resulting in the formation of vacancies. Evaporation from the grain 
boundary leads to a decrease in the mass transfer of the substance, which in turn leads to the appearance of smaller grains $[14,15]$. The importance of small grain size is illustrated in terms of the increased dielectric constant of barium titanate and reduced sensitivity of it to temperature [16].
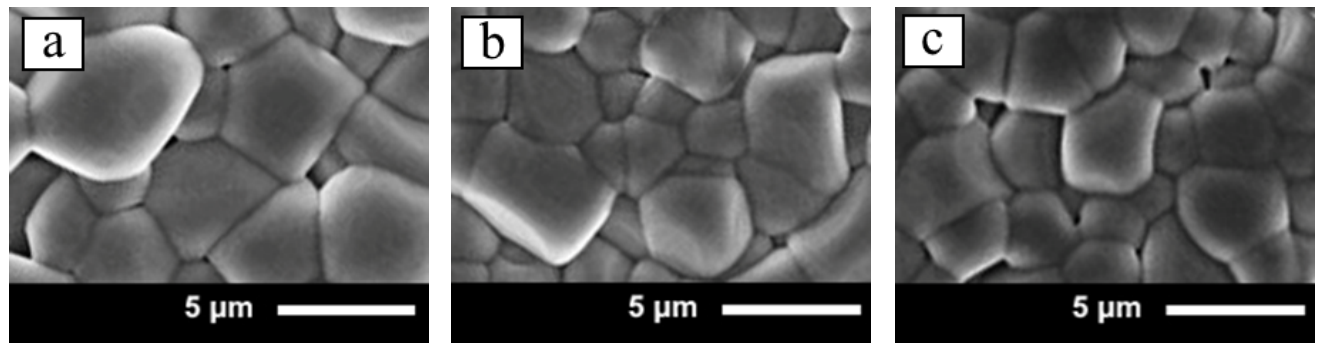

Fig. 4. Micrographs of $\mathrm{La}_{0.5} \mathrm{Li}_{0.5-\mathrm{x}} \mathrm{Na}_{\mathrm{x}} \mathrm{TiO}_{3}$ at $x=0.15$ (a), 0.25 (b), 0.35 (c).
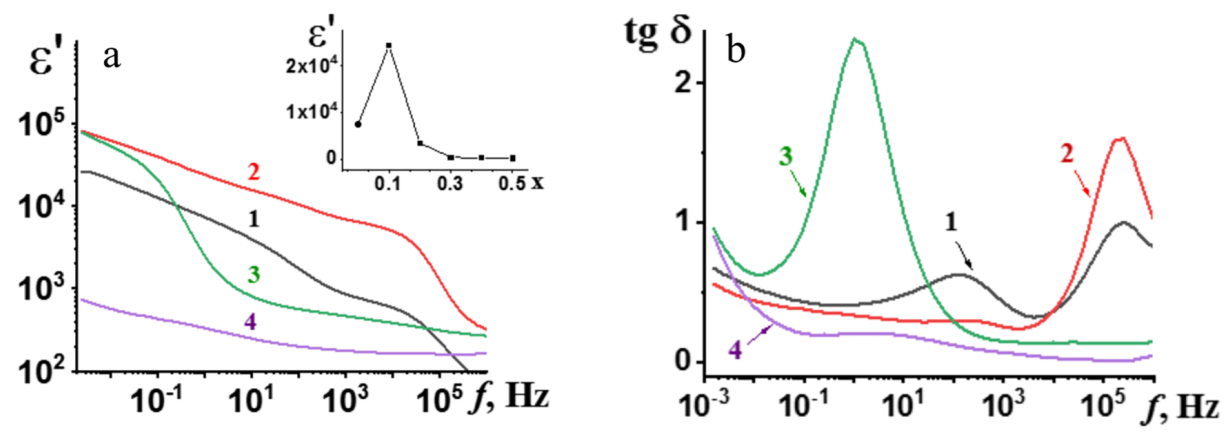

Fig. 5. a - Frequency dependence of dielectric constant $\mathrm{La}_{0.5} \mathrm{Li}_{0.5-\mathrm{x}} \mathrm{Na}_{\mathrm{x}} \mathrm{TiO}_{3}$ solid solutions at $x=0(1)$, $0.1(2), 0.2(3), 0.3(4)$; inset: the dependence of the dielectric constant on $\mathrm{x}$ at a frequency of $1 \mathrm{~Hz}$. b - Frequency dependence of dielectric loss tangent in $\mathrm{La}_{0.5} \mathrm{Li}_{0.5-\mathrm{x}} \mathrm{Na}_{\mathrm{x}} \mathrm{TiO}_{3}$ at $x=0(1), 0.1(2), 0.2(3), 0.3(4)$.

Fig. 5 shows the frequency dependencies of the dielectric constant (Fig. 5a) and dielectric loss tangent (Fig. 5b) at room temperature. Solid solutions $\mathrm{La}_{0.5} \mathrm{Li}_{0.5 \mathrm{x}} \mathrm{Na}_{\mathrm{x}} \mathrm{TiO}_{3}$ with a sodium concentration less than $\mathrm{x}<0.25$ exhibit high dielectric constant $\varepsilon>10^{3}$ at low frequencies $(\mathrm{f} \leq 10 \mathrm{~Hz}$ ). At $\mathrm{x}=0.3$ the dielectric constant gradually decreases, which may be associated with a decrease in the grain size (Fig. 4) and an increase in the total number of grains in the ceramic sample. The mobility of lithium in the grain core is greater than at the grain boundary [16]. As the grain size decreases, the pro- portion of grain boundaries increases, which reduces the contribution to polarization, and the dielectric constant decreases. The dielectric loss tangent (which is determined by the dissipation of energy due to the movement of charges) decreases with an increase in the sodium concentration at frequencies $\mathrm{f}>10^{3} \mathrm{~Hz}$ (Fig. 5b). As can be seen from Fig. 5a, the value of the dielectric constant in the $\mathrm{La}_{0.5} \mathrm{Li}_{0.5-\mathrm{x}} \mathrm{Na}_{\mathrm{x}} \mathrm{TiO}_{3}$ system passes through a maximum in the $\mathrm{La}_{0.5} \mathrm{Li}_{0.4} \mathrm{Na}_{0.1} \mathrm{TiO}_{3}$ solid solution. It is known that in solid solutions where lithium is gradually replaced by sodium in the lanthanum sublattice, the mobility of 
lithium decreases. On the other hand, an increase in the amount of sodium increases the unit cell volume, which expands the distance by which the charge carrier can move (Fig. 2). Described above factors lead to contradictory effects that explain the maximum conductivity in the $\mathrm{La}_{0.5} \mathrm{Li}_{0.4} \mathrm{Na}_{0.1} \mathrm{TiO}_{3}$ solid solution. As at $\mathrm{x}$ $=0.1$ concentration, the number of vacancies and charge carriers $\mathrm{Li}^{+}$is still quite large and there is no Li-ion conduction, which leads to high dielectric response.

\section{CONCLUSIONS. The structure of}

$\mathrm{La}_{0.5} \mathrm{Li}_{0.5-\mathrm{x}} \mathrm{Na}_{\mathrm{x}} \mathrm{TiO}_{3}$ perovskites, with $0<\mathrm{x}<0.5$, has been deduced with the Rietveld method. It has been found that an increase in $\mathrm{x}$ leads to the rise in unit cell volume that can be explained by the rise in the average ionic radius in the lanthanum sublattice. Using X-ray powder diffraction analysis, it has been found that at the first stage two phases of $\mathrm{La}_{0.5} \mathrm{Li}_{0.5} \mathrm{TiO}_{3}$ and $\mathrm{La}_{0.5} \mathrm{Na}_{0.5} \mathrm{TiO}_{3}$ are formed while synthesis of $\mathrm{La}_{0.5} \mathrm{Li}_{0.5-x} \mathrm{Na}_{\mathrm{x}} \mathrm{TiO}_{3}$. The final solid solution is formed by the interaction between lithium-lanthanum titanate and sodium-lanthanum titanate. Intermediate main phases during solid-state reaction synthesis are $\mathrm{La}_{2} \mathrm{O}_{2} \mathrm{CO}_{3}, \mathrm{Li}_{2} \mathrm{TiO}_{3}, \mathrm{Na}_{2} \mathrm{Ti}_{2} \mathrm{O}_{5}, \mathrm{Na}_{2} \mathrm{Ti}_{3} \mathrm{O}_{7}$, $\mathrm{Li}_{2} \mathrm{Ti}_{3} \mathrm{O}_{7}$. Using SEM it has been shown that grain size of ceramics in $\mathrm{La}_{0.5} \mathrm{Li}_{0.5-\mathrm{x}} \mathrm{Na}_{\mathrm{x}} \mathrm{TiO}_{3}$ solid solutions decreases from 4.5 to $3.5 \mu \mathrm{m}$ for $\mathrm{x}=0.15$ and 0.35 , respectively. Impedance spectroscopy has been used to analyze dielectric permittivity and as a result lithium mobility in $\mathrm{La}_{05} \mathrm{Li}_{05-\mathrm{x}} \mathrm{Na}_{\mathrm{x}} \mathrm{TiO}_{3}$ system. The dielectric constant passes through a maximum in $\mathrm{La}_{0.5} \mathrm{Li}_{0.4} \mathrm{Na}_{0.1} \mathrm{TiO}_{3}$ ceramic. This can be explained by the increase in lithium ions mobility due to the growth of unit cell volume which makes a contribution to the polarization and leads to the maximum value of dielectric constant in these materials.
Acknowledgments. The work was supported by the Research program of the Ukrainian National Academy of Sciences "New functional substances and materials for chemical production" (Fine Chemicals), project № 0119 U101351.

\section{ВПЛИВ СИНТЕЗУ НА ДІЕЛЕКТРИЧНІ ВЛАСТИВОСТI La ${ }_{0,5} \mathrm{Li}_{0,5-\mathrm{x}} \mathrm{Na}_{\mathrm{x}} \mathrm{TiO}_{3}$}

Т. О. Плутенко, О. І. В’юнов *, О. П. Федорчук, О. З. Янчевсвкий, А. Г. Білоус

Інститут загальної та неорганічної хімії ім. В. І. Вернадського НАН Украӥни, просп. Акад. Палтадіна 32/34, Київ 03142, Україна *e-mail:vyunov@ionc.kiev.ua

Тверді розчини на основі титанату літію-натрію-лантану $\mathrm{La}_{0,5} \mathrm{Li}_{0,5-\mathrm{x}} \mathrm{Na}_{\mathrm{x}} \mathrm{TiO}_{3}$ синтезовано методом твердофазних реакцій за температур понад $1200{ }^{\circ} \mathrm{C}$. За допомогою методу рентгенівської порошкової дифракції визначено послідовність реакцій, що відбуваються під час синтезу. Встановлено, що на першому етапі синтезу $\mathrm{La}_{0,5} \mathrm{Li}_{0,5-\mathrm{x}} \mathrm{Na}_{\mathrm{x}} \mathrm{TiO}_{3}$ іде одночасне утворення двох перовськитних фаз $\mathrm{La}_{0,5} \mathrm{Li}_{0,5} \mathrm{TiO}_{3}$ та $\mathrm{La}_{0,5} \mathrm{Na}_{0,5} \mathrm{TiO}_{3}$. Кінцевий твердий розчин утворюється при взаємодії між титанатом літію-лантану та титанатом натрію-лантану. Основними проміжними фазами $є \mathrm{La}_{2} \mathrm{O}_{2} \mathrm{CO}_{3}, \mathrm{Li}_{2} \mathrm{TiO}_{3}, \mathrm{Na}_{2} \mathrm{Ti}_{2} \mathrm{O}_{5}$, $\mathrm{Na}_{2} \mathrm{Ti}_{3} \mathrm{O}_{7}, \mathrm{Li}_{2} \mathrm{Ti}_{3} \mathrm{O}_{7}$. За допомогою методу Рітвельда було визначено параметри кристалічної структури $\mathrm{La}_{0,5} \mathrm{Li}_{0,5-\mathrm{x}} \mathrm{Na}_{\mathrm{x}} \mathrm{TiO}_{3}$. Усі зразки системи $\mathrm{La}_{0,5} \mathrm{Li}_{0,5 \mathrm{x}} \mathrm{Na}_{\mathrm{x}} \mathrm{TiO}_{3}$ мають ромбоедричну (тригональну) симетрію з просторовою групою R-3c. Параметри елементарної 
комірки в системі титанатів літію-натрію-лантану змінюються відповідно до закону Вегарда, що свідчить про утворення твердих розчинів. Знайдено, що збільшення х призводить до збільшення об'єму елементарної комірки, що можна пояснити зростанням середнього іонного радіуса в підгратці лантану. За допомогою електронної мікроскопії показано, що розмір зерен зменшується зі збільшенням х у системі $\mathrm{La}_{0,5} \mathrm{Li}_{0,5 \mathrm{x}} \mathrm{Na}_{\mathrm{x}} \mathrm{TiO}_{3}$. Механізми масового транспорту відіграють велику роль під час спікання. 3 одного боку, температура спікання $\mathrm{La}_{0,5} \mathrm{Li}_{0,5-\mathrm{x}} \mathrm{Na}_{\mathrm{x}} \mathrm{TiO}_{3}$ підвищується 3 x, і це повинно призвести до збільшення розміру зерен кераміки. 3 іншого боку, твердий розчин містить іони літію і натрію, які мають тенденцію до випаровування за високих температур, що призводить до утворення вакансій. Утворення вакансій на границях зерен призводить до зменшення масообміну речовини, що, своєю чергою, призводить до появи менших за розміром зерен. Показано вплив розміру зерен кераміки на діелектричні характеристики. За допомогою методу імпедансної спектроскопії було вивчено діелектричні властивості в системі $\mathrm{La}_{0,5} \mathrm{Li}_{0,5-\mathrm{x}} \mathrm{Na}_{\mathrm{x}} \mathrm{TiO}_{3}$. Показано, що значення діелектричної проникності проходить через максимум у кераміці $\mathrm{La}_{0.5} \mathrm{Li}_{0.4} \mathrm{Na}_{0.1} \mathrm{TiO}_{3}$. Це можна пояснити великою кількістю іонів літію та збільшенням їхньої рухливості внаслідок збільшення об’єму елементарної комірки, що дає великий вклад у поляризацію і призводить до максимального значення діелектричної проникності в цих матеріалах.

Ключові слова: твердий розчин, титанат літію-натрію-лантану, перовськит, метод комплексного імпедансу, гігантська діелектрична проникність.

\section{ЛІТЕРАТУРА}

1. Yu K., Tian Y., Gu R., Jin L., Ma R., Sun H., $\mathrm{Xu}$ Y., Xu Z., Wei X. Ionic conduction, colossal permittivity and dielectric relaxation behavior of solid electrolyte $\mathrm{Li}_{3 \mathrm{x}} \mathrm{La}_{2 / 3-\mathrm{x}} \mathrm{TiO}_{3}$ ceramics. Journal of the European Ceramic Society. 2018, 38(13). P. 4483-4487.

https://doi.org/10.1016/j.jeurceramsoc. 2018.05.023.

2. Song F., Yamamoto T., Yabutsuka T., Yao T., Takai Sh. Synthesis and Characterization of LAGP-Based Lithium Ion-Conductive Composites with an LLTO Additive. Journal of Alloys and Compounds. 2021, 853. 157089. https://doi.org/10.1016/j.jallcom.2020.157089.

3. Thangadurai V., Narayanan S., Pinzaru D. Garnet-type solid-state fast Li ion conductors for $\mathrm{Li}$ batteries: critical review. Chemical Society Reviews. 2014, 43. P. 4714-4727. https://doi.org/10.1039/C4CS00020J.

4. Zhang H., Hao S., Lin J. Influence of $\mathrm{Li}_{2} \mathrm{O}-$ $\mathrm{B}_{2} \mathrm{O}_{3}$ glass on ionic migration and interfacial properties of $\mathrm{La}_{2 / 3-x} \mathrm{Li}_{3 \mathrm{x}} \mathrm{TiO}_{3}$ solid electrolyte. Journal of Alloys and Compounds. 2017, 704. P. 109-116.

https://doi.org/10.1016/j.jallcom.2017.02.059.

5. Adachi G., Imanaka N., Aono H. Fast $\mathrm{Li}^{+}$ Conducting Ceramic Electrolytes. Advanced Materials. 1996, 8. P. 127-135. https://doi.org/10.1002/adma.19960080205.

6. Inaguma Y., Liquan C., Itoh M., Nakamura T., Uchida T., Ikuta H., Wakihara M. High ionic conductivity in lithium lanthanum titanate. Solid State Communications. 1993, 86(10). P. 689-693.

https://doi.org/10.1016/0038-1098(93)90841-A.

7. García-Martín S., Morata-Orrantia A., Aguirre M. H., Alario-Franco M. Á. Giant barrier layer capacitance effects in the lithium ion conducting material $\mathrm{La}_{0.67} \mathrm{Li}_{0.25} \mathrm{Ti}_{0.75} \mathrm{Al}_{0.25} \mathrm{O}_{3}$. Applied Physics Letters. 2005, 86. 043110. http://dx.doi.org/10.1063/1.1852717. 
8. Peng Zh., Wang J., Liang P., Zhu J., Zhou X., Chao X., Yang Z. A new perovskite-related ceramic with colossal permittivity and low dielectric loss. Journal of the European Ceramic Society. 2020, 40(12). P. 4010-4015. https://doi.org/10.1016/j.jeurceramsoc.2020. 04.030.

9. Nakamura T., Sun P.-H., Shan Y. J., Inaguma Y., Itoh M., Kim I.-S. On the perovskite-related materials of high dielectric permittivity with small temperature dependence and low dielectric loss. Ferroelectrics. 1997, 196(1). P. 205-209. https://doi.org/10.1080/00150199708224163.

10. Belous A. G., Ovchar O. V. Temperature compensated microwave dielectrics based on lithium containing titanates. Journal of the European Ceramic Society. 2003, 23(14). P. 2525-2528.

https://doi.org/10.1016/S0955-2219(03) 00185-7.

11. Sanz J., Rivera A., León C., Santamaría J., Várez A., V’yunov O., Belous A. G. Li mobility in $(\mathrm{Li}, \mathrm{Na})_{\mathrm{y}} \mathrm{La}_{0.66-\mathrm{y} / 3} \mathrm{TiO}_{3}$ perovskites $(0.09<\mathrm{y} \leq$ $\leq 0.5)$. A model system for the percolation theory. Materials Research Society. 2003, 756. P. 231-236.

https://doi.org/10.1557/PROC-756-EE2.3.

12. Sanjuan M. L., Laguna M. A., Belous A. G., V'yunov O. I. On the local structure and lithium dynamics of $\mathrm{La}_{0.5}(\mathrm{Li}, \mathrm{Na})_{0.5} \mathrm{TiO}_{3}$ ionic conductors. A Raman study. Chem. Mater. 2005, 17. P. 5862-5866.

https://doi.org/10.1021/cm0517770.

13. Herrero C. P., Varez A., Rivera A., Santamarıa J., Leon C., V'yunov O., Belous A. G., Sanz J. Influence of vacancy ordering on the percolative behavior of $\left(\mathrm{Li}_{1-\mathrm{x}} \mathrm{Na}_{\mathrm{x}}\right)_{3 \mathrm{y}} \mathrm{La}_{2 / 3-\mathrm{y}} \mathrm{TiO}_{3}$ perovskites. J. Phys. Chem. B. 2005, 109. P. 3262-3268.

https://doi.org/10.1021/jp046076p.

14. Kambale K., Mahajan A., Butee S.P. Effect of grain size on the properties of ceramics. Metal Powder Report. 2019, 74(3). P. 689-693. http://dx.doi.org/10.1016/j.mprp.2019.04.060.

15. German R. M. Sintering trajectories: description on how density, surface area, and grain size change. The Minerals, Metals \& Materials Society. 2016, 68. P. 878-884. https://doi.org/10.1007/s11837-015-1795-8.

16. Subbarao E.C. Grain size effects in advanced ceramics. Colloids and Surfaces A: Physicochemical and Engineering Aspects. 1998, 133(1-2). P. 3-11.

https://doi.org/10.1016/S0927-7757(97) 00104-0.

\section{REFERENCES}

1. Yu K., Tian Y., Gu R., Jin L., Ma R., Sun H., $\mathrm{Xu}$ Y., Xu Z., Wei X. Ionic conduction, colossal permittivity and dielectric relaxation behavior of solid electrolyte $\mathrm{Li}_{3 \mathrm{x}} \mathrm{La}_{2 / 3-\mathrm{x}} \mathrm{TiO}_{3}$ ceramics. Journal of the European Ceramic Society. 2018. 38 (13): 4483-4487. https://doi. org/10.1016/j.jeurceramsoc.2018.05.023.

2. Song F., Yamamoto T., Yabutsuka T., Yao T., Takai S. Synthesis and Characterization of LAGP-Based Lithium Ion-Conductive Composites with an LLTO Additive. Journal of Alloys and Compounds. 2021. 853: 157089. https://doi.org/10.1016/j.jallcom.2020. 157089.

3. Thangadurai V., Narayanan S., Pinzaru D. Garnet-type solid-state fast Li ion conductors for Li batteries: critical review. Chemical Society Reviews. 2014. 43: 4714-4727. https:// doi.org/10.1039/C4CS00020J.

4. Zhang H., Hao S., Lin J. Influence of $\mathrm{Li}_{2} \mathrm{O}$ $\mathrm{B}_{2} \mathrm{O}_{3}$ glass on ionic migration and interfacial properties of $\mathrm{La}_{2 / 3-x} \mathrm{Li}_{3 \mathrm{x}} \mathrm{TiO}_{3}$ solid electrolyte. Journal of Alloys and Compounds. 2017. 704: 109-116. https://doi.org/10.1016/j.jallcom. 2017.02.059. 
5. Adachi G., Imanaka N., Aono H. Fast $\mathrm{Li}^{+}$ Conducting Ceramic Electrolytes. Advanced Materials. 1996. 8: 127-135. https://doi.org/ 10.1002/adma.19960080205.

6. Inaguma Y., Liquan C., Itoh M., Nakamura T., Uchida T., Ikuta H., Wakihara M. High ionic conductivity in lithium lanthanum titanate. Solid State Communications. 1993. 86 (10): 689-693. https://doi.org/10.1016/00381098(93)90841-A.

7. García-Martín S., Morata-Orrantia A., Aguirre M. H., Alario-Franco M. Á. Giant barrier layer capacitance effects in the lithium ion conducting material $\mathrm{La}_{0.67} \mathrm{Li}_{0.25} \mathrm{Ti}_{0.75} \mathrm{Al}_{0.25} \mathrm{O}_{3}$. Applied Physics Letters. 2005. 86: 043110. http://dx.doi.org/10.1063/1.1852717.

8. Peng Zh., Wang J., Liang P., Zhu J., Zhou X., Chao X., Yang Z. A new perovskite-related ceramic with colossal permittivity and low dielectric loss. Journal of the European Ceramic Society. 2020. 40 (12): 4010-4015. https://doi.org/10.1016/j.jeurceramsoc.2020. 04.030 .

9. Nakamura T., Sun P.-H., Shan Y. J., Inaguma Y., Itoh M., Kim I.-S. On the perovskiterelated materials of high dielectric permittivity with small temperature dependence and low dielectric loss. Ferroelectrics. 1997. 196 (1): 205-209. https:// doi.org/10.1080/00150199708224163.

10. Belous A.G., Ovchar O.V. Temperature compensated microwave dielectrics based on lithium containing titanates. Journal of the European Ceramic Society. 2003. 23 (14): 2525-2528. https://doi.org/10.1016/S09552219(03)00185-7.
11. Sanz J., Rivera A., León C., Santamaría J., Várez A., V’yunov O., Belous A.G. Li mobility in $(\mathrm{Li}, \mathrm{Na}) \mathrm{yLa}_{0.66-\mathrm{y} / 3} \mathrm{TiO}_{3}$ perovskites $(0.09<y \leq 0.5)$. A model system for the percolation theory. Materials Research Society. 2003. 756: 231-236. https://doi. org/10.1557/PROC-756-EE2.3.

12. Sanjuan M. L., Laguna M. A., Belous A. G., V'yunov O. I. On the local structure and lithium dynamics of $\mathrm{La}_{0.5}(\mathrm{Li}, \mathrm{Na})_{0.5} \mathrm{TiO}_{3}$ ionic conductors. A Raman study. Chem. Mater. 2005. 17: 5862-5866. https://doi. org/10.1021/cm0517770.

13. Herrero C. P., Varez A., Rivera A., Santamaria J., Leon C., V'yunov O., Belous A. G., Sanz J. Influence of vacancy ordering on the percolative behavior of $\left(\mathrm{Li}_{1-\mathrm{x}} \mathrm{Na}_{\mathrm{x}}\right)_{3 \mathrm{y}} \mathrm{La}_{2 / 3-\mathrm{y}}$ $\mathrm{TiO}_{3}$ perovskites. J. Phys. Chem. B. 2005. 109: 3262-3268. https://doi.org/10.1021/ jp046076p.

14. Kambale K., Mahajan A., Butee S.P. Effect of grain size on the properties of ceramics. Metal Powder Report. 2019. 74 (3): 689-693. http://dx.doi.org/10.1016/j.mprp.2019.04.060.

15. German R.M. Sintering trajectories: description on how density, surface area, and grain size change. The Minerals, Metals \& Materials Society. 2016. 68: 878-884. https://doi. org/10.1007/s11837-015-1795-8.

16. Subbarao E.C. Grain size effects in advanced ceramics. Colloids and Surfaces A: Physicochemical and Engineering Aspects. 1998. 133 (1-2): 3-11. https://doi.org/10.1016/ S0927-7757(97)00104-0.

Стаття надійшла 20.05.2021. 